\title{
Analisis Perilaku Belajar Siswa Hiperaktif dalam Pembelajaran Matematika
}

\author{
Asdar $^{1, \text { a) }}$, Nasrullah ${ }^{1, \text { b) }}$, dan Alya Dian Sari ${ }^{1, c)}$ \\ ${ }^{1}$ Jurusan Matematika, Fakultas MIPA, Universitas Negeri Makassar \\ a) asdar.ahmad@unm.ac.id \\ ${ }^{b)}$ nasrullah@unm.ac.id \\ a)alyadiansari_24@yahoo.com
}

\begin{abstract}
Abstrak.Penelitian ini bertujuan untuk mengetahui karakteristik perilaku belajar siswa hiperaktif pada pembelajaran matematika.Penelitian ini merupakan penelitian kualitatif deskriptif.Metode pengumpulan data yang diterapkan adalah observasi, wawancara, dan dokumentasi.Instrumen penelitian adalah lembar observasi, pedoman wawancara, serta peneliti itu sendiri.Teknik analisis data dalam penelitian ini adalah reduksi data, penyajian data, dan penarikan kesimpulan Berdasarkan hasil penelitian menunjukkan bahwa 1) perilaku belajar kognitif siswa hiperaktif, khususnya dalam materi perpangkatan. Ada beberapa perilaku yang ditunjukkaan, yaitu: a. pada saat diberikan kuis, siswa mampu menggunakan nalarnya dan siswa mampu mengembangkan pengetahuannya sendiri mengenai jawaban dari permasalahan yang diberikan, meskipun hasil dari jawaban siswa tersebut salah, b. siswa tidak dapat menyelesaikan permasalahan matematika yang bersifat perhitungan perkalian perpangkatan, pembagian perpangkatan, serta sifat perpangkatan yang lainnya, $c$. siswa lamban dalam menerima materi pembelajaran, $d$. siswa tidak dapat berkonsentrasi pada saat proses pembelajaran matematika, ia cenderung menggambar-gambar atau mencoret-coret bukunya. 2) perilaku belajar afektif siswa hiperaktif yang ditunjukkan, yaitu: a. pada saat proses belajar mengajar siswa sering meninggalkan tempat duduk dan sering memukul temannya tiba-tiba, serta berbicara tanpa kendali, b. siswa tidak dapat bertanggungjawab ketika memimpin suatu diskusi kelompok, c. siswa sering melanggar tata tertib sekolah.
\end{abstract}

Kata Kunci:Perilaku Belajar, Pembelajaran Matematika

\begin{abstract}
This study aims to determine the characteristics of hyperactive student learning behavior in mathematics. This is a descriptive qualitative research. The data collection methods werethe observation, interview, and documentation. The research instrument was the observation sheet, interview guidelines, and the researcher himself. The data analysis techniques are data reduction, data presentation, and drawing conclusions. The results of the study showed that 1) the cognitive learning behavior of hyperactive students, especially in the topic about exponent. There are several behaviors that are indicated, namely: a. given a quiz, students are able to use their reasoning and to develop their own knowledge about the answers to the problems given, even though the results of students' answers are wrong, b. students cannot solve mathematical problems that are the calculation of rank multiplication, division of rank, and the nature of the other ranks, $c$. students are slow in accepting learning material, $d$. students cannot concentrate on the process of learning mathematics, he tends to draw pictures or doodle on his book. 2) the affective learning behavior of hyperactive students shown, namely: a. when the learning process students often leave their seats and often hit their friends suddenly, and speak without control, b. students cannot be held responsible when leading a group discussion, $c$. students often violate school rules.
\end{abstract}

Keywords: Learning Behavior, Mathematics Learning 


\section{PENDAHULUAN}

Dalam kehidupan sehari-hari, siswa sering menghadapi masalah-masalah dalam rangka beradaptasi dengan lingkungannya. Berbagai masalah timbul karena kurangnya keselarasan perkembangan siswa, salah satu faktornya adalah sosio-emosional, dimana siswa sukar berhubungan dengan orang lain, belum dapat mengikuti aturan-aturan secara penuh, sering membangkang jika keinginannya tidak dituruti, kesulitan dalam menangkap apa yang diterima oleh pengamatan inderanya, serta sulit untuk memusatkan perhatian bahkan dapat menunjukkan perilaku hiperaktif (Ernawati, 2005).

Anak hiperaktif merupakan anak yang mengalami gangguan pemusatan perhatian dengan hiperaktivitas atau Attention Deficit and Hyperactivyty Disorder (ADHD) (Zaviera, 2014).Gangguan perilaku ini ditandai dengan adanya gangguan pemusatan perhatian, permbicaraan yang lepas kontrol, serta gerakan yang berlebihan melebihi gerakan yang dilakukan anak pada umumnya (Wiyani, 2014).Mereka kurang mampu mengontrol dan melakukan koordinasi dalam aktivitas motoriknya, sehingga tidak dapat membedakan mana gerakan penting dan gerakan tidak penting.Mereka melakukan gerakan tersebut secara terusmenerus tanpa mengenal lelah.Hal ini menyebabkan mereka kesulitan dalam memusatkan perhatiannya (Koasih, 2012).

Anak yang menderita ADHD akan impulsif sehingga melakukan sesuatu tanpa berpikir. Selain itu, anak merasakan kegelisahan yang berlebihan, mudah merasa terganggu serta biasanya mengalami kesulitan dalam pelajaran khususnya kesulitan untuk berkonsentrasi atau fokus pada materi pelajaran.Melinda(2013), menjelaskan tipe hiperaktif. Hiperaktif dibagi menjadi 3 tipe, yaitu: tipe yang tidak bisa memusatkan perhatian, tipe yang hiperaktif dan impulsive serta tipe gabungan dari keduanya.

Ciri utama anak ADHD ditunjukkan dengan rentang perhatian yang kurang, impulsivitas yang berlebihan, dan adanya hiperaktivitas. Perilaku ADHD yang tampak seperti sering tidak bisa memberi perhatian untuk hal-hal yang bersifat rinci, mudah terganggu, tidak bisa duduk diam, sering meninggalkan tempat duduk saat di kelas, sering berlari-lari, dan badannya seperti digerakkan oleh mesin, serta anak ini juga sering berbicara berlebihan dibandingkan dengan anak seusianya (Fatwa, 2009).

Terdapat beberapa penelitian yang berkaitan dengan perilaku siswa hiperaktif (Novriana, Yanis, \& Masri, 2014; Aulia, 2016; Kusumawati, 2010; Sultan, 2011).Aulia (2016) dalam penelitiannya mengungkapkan bahwa problematika yang dihadapi adalah susahnya mengatur jalannya pembelajaran di dalam kelas, dikarenakan kelas didominasi oleh beberapa anak hiperaktif (ADHD).Upaya yang dilakukan guru adalah dengan perlahan melakukan pendekatan terhadap siswa hiperaktif dalam pembelajaran.

Selain itu Novriana, dkk (2014) mengungkapkan bahwa prevalensi gangguan pemusatan perhatian dan hiperaktivitas (GPPH) adalah $8 \%$ dengan perbandingan antara laki-laki dan perempuan 2:1. Prevalensi GPPH terbanyak ditunjukkan pada kategori usia 11-13 tahun dan subtype munculan terbanyak adalah subtipe predominan hiperaktivitas-impulsivitas.

Anak yang mengalami gangguan hiperaktifitas menunjukkan perilaku berlebihan, mereka tidak bisa tenang walaupun kondisi menuntut untuk tenang. Sangat jelas sekali terlihat apabila mereka berada dalam sebuah kelas.Selalu saja mereka melakukan sesuatu, seperti mengganggu temantemannya. Ketika guru menerangkan sesuatu, maka anak akan cenderung tidak memperhatikan, konsentrasi mereka mudah sekali teralihkan sehingga ketika kita berbicara kepada mereka sangat mungkin bila tiba-tiba dia langsung pergi meninggalkan kita untuk melakukan hal lain yang menurut mereka menarik.

Berdasarkan hasil observasi yang dilakukan di salah satu Sekolah Menengah Pertama di Makassar, terdapat siswa yang menunjukkan sikap hiperaktif.Khususnya dalam pembelajaran 
matematika.Hal ini ditandai dengan sikap siswa yang tidak bisa diam dalam kelas, cenderung mencari perhatian guru maupun teman sekelasnya. Bukan hanya itu, siswa seringkali tidak fokus pada saat guru menjelaskan, perhatiannya mudah teralihkan oleh hal-hal yang menurutnya lebih menarik, sering membuat keadaan kelas tidak terkontrol, dan selalu mengajak temannya untuk berbicara sehingga siswa yang lain pun tidak bisa menerima materi yang diajarkan dengan baik.Penelitian ini bertujuan untuk mengetahui perilaku belajar siswa hiperaktif pada pembelajaran matematika dan untuk mengetahui gambaran prestasi belajar siswa hiperaktif.

\section{KAJIAN PUSTAKA}

\section{Pengertian Hiperaktif}

Ditinjau secara psikologis, hiperaktif adalah gangguan tingkah laku yang tidak normal, disebabkan disfungsi neurologis dengan gejala utama tidak mampu memusatkan perhatian. Anak dengan gangguan hiperaktivitas tidak bisa berkonsentrasi lama lebih dari lima menit. Dengan kata lain, siswa hiperaktif tidak bisa diam dalam waktu lama dan mudah teralihkan perhatiannya pada hal lain (Zaviera, 2014).

ADHD merupakan anak yang memperlihatkan simtom-simtom (ciri atau gejala) kurang konsentrasi, hiperaktif, dan impulsif yang dapat menyebabkan ketidakseimbangan sebagian besar kehidupan mereka(Rofiah, 2018).Perilaku dengan gangguan pemusatan perhatian/hiperaktif adalah anak yang sulit melakukan seleksi tahap stimulus yang ada di sekitarnya, yang berakibat sulit dalam memusatkan perhatiannya dan menjadi bertindak tanpa berpikir, tidak dapat menahan marah, kekecewaan dan atau suka mengganggu.

Hiperaktif adalah suatu peningkatan aktivitas motorik hingga pada tingkatan tertentu dan menyebabkan gangguan perilaku yang terjadi pada dua tempat dan suasana yang berbeda (Prasetyono, 2008).Widodo (2009) menjelaskan gangguan pemusatan perhatian ADHD ditandai dengan adanya ketidakmampuan anak untuk memusatkan perhatiannya pada sesuatu yang dihadapi.Selanjutnya, ADHD adalah suatu kondisi kesehatan yang kompleks dengan karakteristik ketidakmampuan untuk mengumpulkan dan mempertahankan perhatian, memodulasi tingkat aktivitas, dan tindakan impulsif moderat (Aprilia \& Oktaria, 2017).

Ada beberapa ciri anak hiperaktif yang dikemukakan oleh Zumaroh (2017) diantaranya adalah: 1. Tidak fokus, 2. Sifat Menentang, 3. Destruktif, 4. Tidak mengenal lelah, 5. Tanpa Tujuan Jelas, 6. Bukan penyabar yang baik dan usil dan 7. Intelektualitas Rendah.Ketujuh karakteristik tersebut, Wiyani (2014) menambahkan secara rinci karakteristik anak hiperaktif antara lain: 1). Anak sering gelisah yang terlihat pada tangan atau kaki mereka, 2). Anak berbicara berlebihan atau tidak bisa berhenti bicara, 3). Anak mengalami kesulitan dalam bermain atau terlibat dalam kegiatan secara tenang, 4). Anak bergerak atau bertindak seolah-olah dikendalikan oleh mesin, dan 5). Anak tidak bisa duduk tenang dalam waktu lama (lebih lima menit).

Selain itu, ada beberapa karakteristik anak hiperaktif lainnya yang dikemukakan oleh (Zaviera, 2014), seperti 1). Anak sering melakukan kecerobohan atau gagal menyimak dan sering membuat kesalahan karena tidak cermat, 2).Sering tidak mengikuti instruksi dan gagal menyelesaikan tugasnya, 3). Tidak mendengarkan lawan bicaranya, 4).Sering menghindar atau tidak menyukai melakukan tugas yang membutuhkan pemikiran lama, 5).Sering kehilangan barang yang dimilikinya, 6).Sering lupa mengerjakan tugas sehari-hari, 7).Perhatiannya mudah teralih oleh rangsangan dari luar.

Berdasarkan penelitian yang dilakukan oleh Aprilia \& Oktaria (2017), menunjukkan bahwa individu dengan ADHD pada umumnya memiliki kemampuan akademik yang lebih rendah dan sulit melanjutkan ke jenjang pendidikan lebih tinggi karena kesulitan dalam mempertahankan 
perhatian (atensi), hiperaktivitas, dan impulsive. Namun, terdapat subpopulasi yang memiliki kemampuan kognitif yang lebih tinggi dan catatan keberhasilan akademis yang lebih besar dan menunjukkan kemampuan kompensasi yang adatif.

\section{METODE PENELITIAN}

Jenis penelitian adalahpenelitian studi kasus. Subjek dalam penelitian ini berjumlah 1 orang(IMB) yang memenuhi karakteristik dari siswa hiperaktif, yaitu 1) anak sering gelisah yang terlihat pada tangan atau kaki mereka, 2) anak berbicara berlebihan atau tidak bisa berhenti bicara, 3) anak tidak bisa duduk tenang dalam waktu yang lama, 4) sering lupa mengerjakan tugas sehari-harinya.

Teknik pengumpulan data dalam penelitian ini yaitu observasi untuk menentukan apakah anak tersebut siswahiperaktif, wawancara digunakan untuk menggali data-data yang tidak semuanya dapat dijelaskan malalui observasi, serta dokumentasi digunakan untuk mendapatkan data prestasi belajar siswa hiperaktif.Instrumen yang digunakan adalah lembar observasi dan pedoman wawancara yang telah divalidasi oleh dua orang ahli.

Pengambilan data dalam penelitian ini dimulai dengan tahap observasi yang dilakukan oleh peneliti untuk menentukan siswa tersebut masuk dalam karakteristik hiperaktif.Langkah selanjutnya adalah melakukan wawancara kepada teman kelas dan guru matematika dari siswa hiperaktif.Data dari hasil wawancara tersebut kemudian dideskripsikan. Deskripsi dari wawancara yang dilakukan akan menggambarkan karakteristik siswa hiperaktif serta prestasi belajar dari siswa hiperaktif. Kemudian yang terakhir adalah penyajian data, data hasil wawancara tersebut disajikan dalam bentuk uraian.

\section{PEMBAHASAN}

\section{Deskripsi Siswa Hiperaktif}

IMB merupakan salah satu siswa kelas IX di salah satu sekolah menengah pertama di Makassar.IMB merupakan anak kedua dari tiga besaudara.IMB mempunyai hobi bermain game.

Ciri-ciri anak hiperaktif (IMB) yang paling menonjol adalah; pertama, IMB tidak dapat memperhatikan dan mendengarkan gurunya dengan baik. Hal ini ditandai pada saat proses belajar mengajar berlangsung IMB sering melamun, pandangannya mengarah keluar pintu kelas, serta menggambar-gambar tidakjelas di buku tulisnya.

Kedua, IMB selalu mencari perhatian terhadap gurunya maupun teman kelasnya. Pada saat guru menjelaskan ia sering berbicara diluar dari materi yang diajarkan, menjawab sebelum pertanyaan selesai, serta mengganggu teman sebangkunya maupun yang berada di dekat tempat ia duduk.

Ketiga, IMB tidak menyelesaikan pekerjaannya dengan baik dan sering mengabaikan tugas yang diberikan oleh gurunya.Apabila diberikan tugas harian IMB sering mengabaikannya. Begitu pula ketika diberikan tanggungjawab seperti jadwal piket, ia jarang sekali mengerjakannya.

\section{Perilaku Belajar Kognitif Siswa Hiperaktif}

Berikut disajikan hasil kuis dan wawancara subjek IMB 
Pada Gambar 1, terlihat IMB menjawab kuis dengan pemahamannya sendiri. Hal ini dipertegas pada Transkrip 1.

\section{TRANSKRIP 1}

$$
\begin{array}{ll}
\text { P-001-a } & : \text { Kenapa nomor } 1 \text { bagian a hasilnya }-2^{4} \text { ? } \\
\text { IMB-001-a } & : \text { Karena ini, }-2 \text { nya ada empat kali } \\
P-001-a & : \text { Ndak dikasih dalam kurung -2 nya? } \\
\text { IMB-001-a } & : \text { Sama ji hasilnya }
\end{array}
$$

Transkrip 1 menunjukkan bahwa IMB menjelaskan cara menyelesaikan bentuk perkalian pada perpangkatan. IMB mengabaikan penggunaan tanda kurung yang menyebabkan hasil yang ia dapatkan salah. Kemudian pada bagian b, tanggapan IMB masih sama seperti pada bagian a.

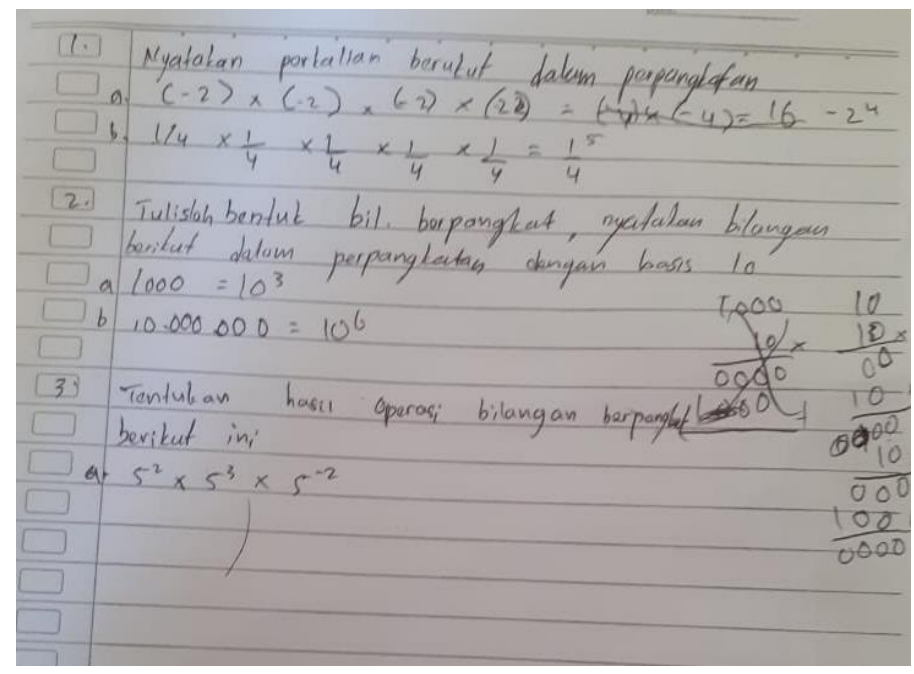

GAMBAR 1. Hasil Kuis Siswa Hiperaktif

\section{TRANSKRIP 2}

\section{$P-002-b \quad \therefore$ Pada soal nomor 2 bagian $b$, kenapa hasilnya bisa $10^{6}$ ? \\ IMB-002-b : Karena itu 10 sebelum titik basisnya, kemudian itu mi nol yang terakhir dihitung}

Selain hasil kuis, peneliti melakukan wawancara dengan guru matematika dan teman kelas dari IMB. Dari hasil wawancara tersebut peneliti mendapatkan informasi bahwa IMB sering tidak fokus pada saat guru menjelaskan, hal ini ditandai ketika gurunya sedang menyampaikan materi, IMB malah menggambar-gambar atau mencoret-coret tidak jelas, sering mengalihkan perhatiannya kearah luar pintu, ia lebih tertarik untuk memperhatikan kelas lain yang sedang berolahraga, lamban dalam menerima materi, serta jarang mengerjakan tugas yang diberikan oleh gurunya.

Berikut adalah hasil wawancara dengan guru matematika dan teman kelas dari IMB:

\section{TRANSKRIP 3}

WWc.P3-001 : Apakah subjek memperhatikan dan mendengarkan dengan baik apa yang dijelaskan oleh guru pada saat KBM berlangsung?

WWc.J3-001 : Tidak, dia lebih cenderung memperhatikan hal-hal yang dominan yang menurutnya lebih menarik untuk diperhatikan ketimbang penjelasan dari guru. Seperti misalnya, kalau ada teman-temannya yang sedang berolahraga, fokusnya selalu keluar kelas.

WWc.P3-003 : Apakah subjek ini sering mengerjakan tugas yang ibu berikan?

WWc.J3-003 : Jarang sekali 
WWc.P3-004 : Apakah subjek menerima materi dengan cepat atau lamban?

WWc.J3-004 : Lamban, bahkan dijelaskan berulang-ulang pun si anak kadang mengerti kadang tidak.

Transkrip 3 menunjukkan bahwa IMB tidak dapat memperhatikan dan mendengarkan gurunya dengan baik pada saat proses KBM berlangsung, dia lebih cenderung memperhatikan hal-hal dominan yang menurutnya lebih menarik untuk diperhatikan. Hal tersebut dapat dilihat pada (WWc.J3-001). Selanjutnya, dalam penerimaan materi pun IMB lamban dalam menangkapnya atau bahkan tidak mengerti sama sekali apa yang dijelaskan oleh gurunya. Apabila ada pertanyaan-pertanyaan yang guru ajukan kepada IMB, ia kadang diam kadang juga merespon. Itupun respon yang diberikan tidak sesuai dengan pertanyaan yang diberikan.

\section{TRANSKRIP 4}

WWc.P2-005 : Apakah dia pernah memberikan solusi atau pendapat pada saat kalian diberikan permasalahan dalam bekerja kelompok?

WWc.J2-005 : Jarang, ribut ji na kerja. Main-main, biasa juga menggambar-menggambar.

WWc.P2-006 : Apabila ada tugas yang diberikan, apakah subjek mengerjakannya?

WWc.J2-006 : Disuruh pi baru na kerja, biasa na kerja biasa juga tidak. Tapi, lebih banyak tidak.

Transkrip 4menunjukkan bahwaIMB jarang sekali mengerjakan tugasnya (WWc.J2-006). IMB mengerjakan tugasnya ketika berhadapan dengan guru-guru killer, itupun tugasnya tidak ia kerjakan sendiri, melainkan menyalin tugas dari teman-temannya. Selain itu, IMB sering berbicara diluar dari materi yang diajarkan oleh gurunya.

Saat pembelajaran kelompok, IMB tidak memberikan kontribusi apapun terhadap kelompoknya.Ia tampak biasa-biasa saja terhadap tugas dan tanggung jawab kelompok yang diberikan kepadanya. IMB kebanyakan mondar-mandir tidak jelas, selalu keluar dari bangkunya. Pun tidak berusaha membantu teman kelompoknya untuk menyelesaikan permasalahan yang diberikan kepada kelompoknya tersebut.

\section{Perilaku Belajar Afektif Siswa Hiperaktif}

Pada saat proses pembelajaran, IMB menunjukkan perilaku yang berbeda dengan temannya yang lain. Hal ini diungkap pada saat wawancara dengan guru dan teman dari IMB.

\section{TRANSKRIP 5}

WWc.P3-004 : Apakah IMB sering memberikan jawaban sebelum pertanyaan ibu selesai?

WWc.J3-004 : Sering, tapi jawaban yang dia berikan tidak sesuai dengan apa yang ditanyakan.

WWc.P3-012 : Apakah anak bergerak lebih aktif dari anak yang lain?

WWc.J3-012 : Yaa, dia lebih banyak bergerak dari temannya yang lain, tap gerakangerakannya tidak menghasilkan sesuatu yang bermakna.

Transkrip 5 memberikan informasi bahwa IMB merupakan siswa yang lebih aktif dari temannya yang lain (WWc.J3-012).Selain itu IMB seringkali memotong pembicaraan atau menjawab pertanyaan-yang diberikan oleh guru, namun jawaban yang diberikan tidak sesuai dengan pertanyaan (WWc.J3-004).

\section{TRANSKRIP 6}

WWc.P3-009 : Apakah pada saat temannya yang lain mengerjakan tugas atau sedang belajar si IMB ini sering mengganggu temannya yang lain?

WWc.J3-009 : Dia berusaha untuk mengganggu temannya supaya temannya itu meladeni apa yang dia bicarakan.

WWc.P3-012 : Apakah sikap aktifnya ini berlaku khusus di mata pelajaran Matematika saja atau semua mata pelajaran? 


\section{WWc.J3-012 : Semua mata pelajaran kak}

Transkrip 6, teman kelas dari IMB menjelaskan bahwa IMB mengganggu temannya pada saat guru menjelaskan, serta sering memotong pembicaraan orang lain. Selain itu, sikap aktif IMB tidak hanya ditunjukkan pada saat jam pelajaran matematika saja, akan tetapi pada semua mata pelajaran (WWc.J3-01). Dilain sisi, IMB merupakan siswa yang disiplin waktu. Hal ini dibuktikan dengan kehadiran siswa yang selalu tepat waktu di sekolah, ia selalu datang lebih awal dibanding teman kelasnya yang lain.

\section{Prestasi Belajar Siswa Hiperaktif}

Berdasarkan data dokumen raport IMB pada kelas VII semester ganjil dan genap, berikut adalah hasil prestasi belajar matematika IMB:

\section{Prestasi belajar matematika semester ganjil}

Gambar 2 merupakan hasil prestasi belajar IMB kelas VII semester ganjil.IMB mendapatkan predikat baik dengan nilai 81.Berdasarkan hasil raport, IMB memiliki penguasaan pengetahuan yang baik terutama pada penyelesaian persamaan dan pertidaksamaan linear satu variabel. Tampak juga bahwa nilai matematika IMB lebih tinggi disbanding dengan beberapa mata pelajaran lain seperti Pendidikan Agama, Bahasa Indonesia, IPS, serta Seni Budaya.

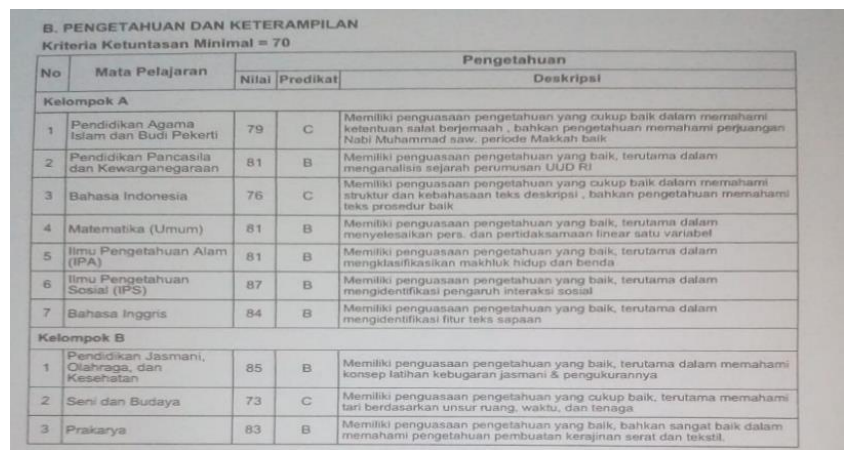

GAMBAR 2. Prestasi Belajar IMB Kelas VII Semester Ganjil

Prestasi belajar matematika semester genap

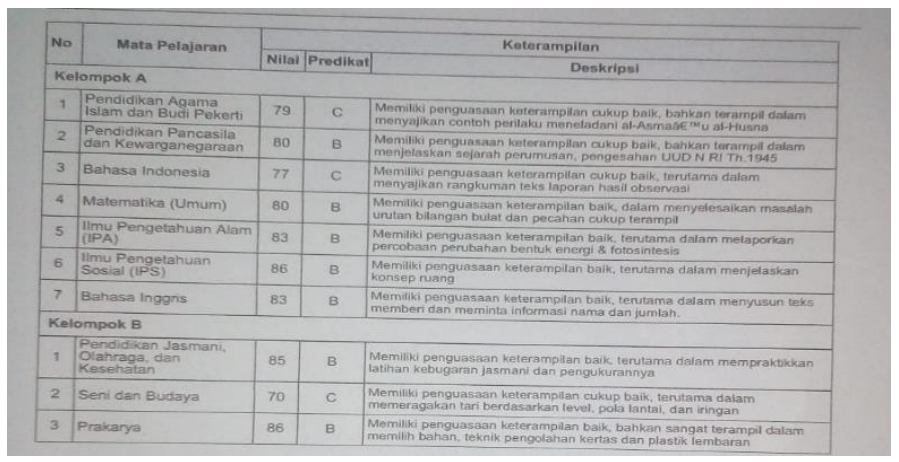

GAMBAR 3. Prestasi Belajar IMB Kelas VII Semester Genap

Gambar 3 merupakan hasil prestasi belajar IMB kelas VII semester genap.IMB mendapatkan predikat baik dengan nilai 80.Nilai matematika dari IMB dari semester ganjil ke genap mengalami penurunan, meskipun penurunannya tidak terlalu jauh.IMB memiliki penguasaan pengetahuan yang baik, terutama dalam membedakan perbandingan senilai dan berbalik nilai. 
Selain itu, nilai matematika IMB lebih baik dibandingkan dengan mata pelajaran lain seperti: Pendidikan Agama, Bahasa Inggris, serta Seni Budaya.

Melihat karakteristik IMB, maka peneliti membuat kesimpulan bahwa perilaku IMB sesuai dengan teori karakteristik anak hiperaktif yang diungkapkan Zaviera (2014) dan Wiyani (2014). Beberapa karakteristrik anak hiperaktif menurut Zaviera (2014), yaitu 1) Tidak fokus, 2) Sifat menentang, 3) Destruktif, 4) Tidak mengenal lelah, 5) Tanpa tujuan yang jelas, 6) Bukan penyabar yang baik dan usil, dan 7) Intelektualitas rendah.

Wiyani (2014) menambahkan karakteristik anak hiperaktif antara lain: 1) anak sering gelisah yang terlihat pada tangan atau kaki mereka, 2) anak berbicara berlebihan atau tidak bisa berhenti bicara, 3) anak mengalami kesulitan dalam bermain atau terlibat dalam kegiatan secara tenang, 4) anak bergerak atau bertindak seolaah-olah dikendalikan oleh mesin, dan 5) anak tidak bisa duduk tenang dalam waktu yang lama (lebih lima menit).

Selain itu, peneliti melihat perilaku IMB menunjukkan anak hiperaktif tipe hiperaktif-impulsif. Peneliti menyimpulkan demikian karena perilaku yang ditunjukkan IMB sesuai dengaan teori DSM IV®- TR tentang anak hiperaktif tipe hiperaktif-impulsif, diantaranta 1) sering meninggalkan tempat duduk, 2) melakukan aktivitas motoric secara berlebihan, 3) berbicara secara berlebihan, 4) sering menjawab tanpa berpikir sebelum pertanyaan selesai diberikan, 5) tidak teratur dalam mengerjakan tugas, dan 6) sering menyela pembicaraan orang lain.

\section{KESIMPULAN}

1. Tipe hiperaktif siswa yang diamati pada pembelajaran ini adalah tipe hiperaktif-impulsif dengan karakteristik perilaku sebagai berikut:

1) Perilaku Belajar Kognitif

a. Pada saat diberikan kuis, siswa mampu menggunakan nalarnya dan siswa mampu mengembangkan pengetahuannya sendiri mengenai jawaban dari permasalahan yang diberikan, meskipun hasil dari jawaban tersebut salah.

b. Siswa tidak dapat menyelesaikan permasalahan matematika yang bersifat perhitungan perkalian perpangkatan, pembagian perpangkatan, serta sifat perpangkatan yang lainnya.

c. Siswa lamban dalam menerima materi pembelajaran dan juga siswa sulit berkonsentrasi pada saat proses pembelajaran berlangsung, ia cenderung menggambar-gambar atau mencoret-coret sembarang di buku tulisnya.

2) Perilaku Belajar Afektif

a. Pada saat proses belajar mengajar matematika, IMB sering kali menunjukkan tingkah laku seperti: meninggalkan tempat duduk, sering memukul temannya tiba-tiba, tidak mendengarkan apa yang diinstruksikan oleh guru, serta berbicara tanpa kendali.

b. Apabila diberikan tanggung jawab untuk memimpin suatu diskusi kelompok, IMB cenderung mengabaikannya. Ia lebih memilih untuk berjalan mondar-mandir ataupun mengganggu kelompok yang lainnya.

c. Pada aspek kedisiplinan, IMB merupakan siswa yang disiplin waktu. Hal ini dibuktikan dengan kehadiran siswa yang selalu tepat waktu di sekolah, ia selalu datang lebih awal dibanding teman kelasnya yang lain.

2. Prestasi belajar matematika siswa hiperaktif

1) Berdasarkan hasil raport kelas VII semester ganjil dan genap, IMB memiliki penguasaan pengetahuan yang baik pada materi tertentu, salah satunya pada materi penyelesaian persamaan dan pertidaksamaan linear satu variabel. 
2) Prestasi belajar matematika lebih baik dibandingkan dengan mata pelajaran lainnya, seperti: Pendidikan Agama, IPS, serta Seni Budaya.

\section{DAFTAR PUSTAKA}

Aprilia, E., \& Oktaria, D. (2017).Kemampuan Akademik Penderita Attention DeficitHyperactivity Disorder (ADHD) pada Tingkat Perguruan Tinggi. Majority., 7(1). 165.

Aulia, I. A. (2016).Problematika Siswa Hiperaktif dalam Proses Penerimaan Pembelajaran Kelas V di Madrasah Ibtidaiyah Plus Sabilul Muhtadin Pakisrejo. (Skripsi, Diterbitkan). Universitas Islam Negeri Maulana Malik Ibrahim, Malang.

Ernawati.(2005). Penggunaan Media Visual Dalam Pembelajaran Anak Hiperaktif. (Tesis, Diterbitkan). Universitas Negeri Semarang, Semarang.

Fatwa, T. (2009). Peran Orang Tua dan Guru dalam Menangani Perilaku Hiperaktiifitas pada Anak ADHD di SLB Negeri 3 Yogyakarta. Jurnal Penelitian dan Kajian Ilmiah Kesehatan Masyarakat, 3 (1). 51.

Melinda. (2013). Anak Hiperaktif Penyebab dan Cara Mengatasinya.http://www.melindahospital.com/modul/user/detail_artikel.php?id=1001 Anak-Hiperaktif:-Penyebab-dan-Cara-Mengatasinya. Diakses tanggal 16 Oktober 2019.

Koasih, E. (2012). Cara Bijak Memahami anak Berkebutuhan Khusus .Bandung : Yrama Widya.

Kusumawati, E. (2010). Studi Kasus Perilaku Hiperaktif dan Faktor Penyebabnya Pada Siswa Kelas III SD Negeri Mraggen 05 Kecamatan Polokarto Kabupaten Sukoharjo Tahun Pelajaran 2009/2010. (Skripsi, Diterbitkan). Universitas Negeri Sebelas Maret, Surakarta.

Novriana, D.E, Yanis,A., \&Masri, M. (2014). Prevalensi Gangguan Pemusatan Perhatian dan Hiperaktivitas pada Siswa dan Siswi Sekolah Dasar Negeri Kecamatan Padang Timur Kota Padang. Jurnal Kesehatan Andalas, 3(2). 141.

Prasetyono.(2008). Serba-serbi Anak Autis. Yogyakarta: Diva Press.

Rofiah, N.H. (2018). Perilaku Attention Deficit Hyperactivyty Disorder (ADHD) dalam Proses Pembelajaran (Studi Kasus Peserta Didik) di Kelas IV SD Negeri Gejayan). Fundadikdas. , 1(1). 65.

Sultan.(2011). Perilaku Hiperaktif Siswa di SMP Negeri 2 Pinrang.http://ejurnal.stainparepare.ac.id.Diakses pada 16 Oktober 2019.

Widodo, J. (2009). Penatalaksanaan Attention Deficit Hyperactive Disorders Pada Anak.http://puterakembara.org/rm/adhd.shtml. Diakses tanggal 16 Oktober 2019.

Wiyani, A.N. (2014). Penanganan Anak Usia Dini Berkebutuhan Khusus. Yogyakarta:Ar-Ruzz Media.

Zaviera, F. (2008).Anak Hiperaktif. Yogyakarta: Kata Hati.

Zumaroh, Nova Triana. 2017. Peningkatan Kemampuan Membaca, Menulis Dan Menghitung Pada Siswa Hiperaktif Kelas II MI Mambaul Ulum Sepanjang Gondanglegi Malang. (Skripsi, Diterbitkan). Universitas Islam Negeri Maulana Malik Ibrahim, Malang. 